\title{
Occurrence of oral neoplasms and dysplastic lesions: retrospective study of a pathology service over a 19-years period
}

\author{
Ocorrência de neoplasias e lesões displásicas \\ orais: estudo retrospectivo de um serviço de \\ patologia em um período de 19 anos
}

\author{
Mariana Silva Araújo de Assis' ${ }^{1}$ (D) \\ Sílvia Regina de Almeida Reis² (D) \\ Alena Peixoto Medrado3
}

1,2BAHIANA - School of Medicine and Public Health. Salvador, Bahia, Brazil. marianaassis16.1@bahiana.edu.br, srareis@bahiana.edu.br ${ }^{3}$ Corresponding author. BAHIANA - School of Medicine and Public Health. Salvador, Bahia, Brazil. apmedrado@bahiana.edu.br

ABSTRACT | INTRODUCTION: The epidemiological survey of the maxillofacial pathologies is of fundamental importance to prevention and treatment of these lesions. OBJECTIVE: The aim of the present study was to collect and analyze histopathological reports of biopsies sent to the Pathology Department, School of Dentistry from EBMSP. METHODS: A retrospective study of biopsies realized from 2001 to 2019 was conducted and the diagnoses of oral neoplasms and epithelial dysplasias were collected and analyzed. Data related to sex and age of the patients, location of the lesions, and clinical and histopathological diagnosis were recovered. RESULTS: From the total of 3.068 biopsies received in this period, the oral neoplasms corresponded to $16,9 \%$ of this total. Patients of the female sex $(55,3 \%)$ and individuals between 25 and 64 years of age $(60,3 \%)$ were most affected by neoplasms. The most common diagnosis among benign neoplasms was the ameloblastoma $(20,3 \%)$ and the squamous cells carcinoma $(67,2 \%)$ was the most frequent diagnosis in the group of malignant neoplasms. The anatomical location most affected by the neoplasms was the jaw $(36,7 \%)$. The epithelial dysplasias corresponded to $3,8 \%$ of the sample, with a higher occurrence in the male sex $(50,8 \%)$ and the age group between 25 and 64 years (61\%); the anatomical location most affected was the palate $(22,8 \%)$, and the mild epithelial dysplasia $(68,6 \%)$ was the most common diagnosis. CONCLUSION: The present study highlights the importance of the epidemiological surveys to prevention and treatment of the maxillofacial lesions and emphasizes the necessity of the appropriate filling out of biopsies files.

KEYWORDS: Oral neoplasms. Diagnosis. Epidemiology. 


\section{Introduction}

Neoplasms represent an abnormal growth of tissue consisting of cell replication, which are independent of the regulation of normal cell growth. Tumors can develop in various sites, including the oral cavity, and are classified as benign or malignant according to the degree of cell differentiation, growth rate, and ability to invade and develop metastasis ${ }^{1}$.

Most benign neoplasms exhibit a high degree of differentiation and slow growth, are well defined, and do not develop metastasis. Malignant neoplasms have anaplastic cells, that is, with marked loss of differentiation due to high mitotic activity. The malignancy of these lesions can also be distinguished by rapid growth and the ability to infiltrate surrounding tissues and metastasize ${ }^{1}$.

"The epithelial dysplasias, a disorderly but nonneoplastic proliferation, may present a loss of uniformity of cells and of their architecture, pleomorphism and abnormally large hyperchromatic nuclei. Dysplasias can be classified as mild, moderate and severe and when the dysplastic alterations are marked and involve the entire epithelium, the lesion is called carcinoma in situ, a premalignant disorder ${ }^{11}$.

The primary objective of epidemiological research on the occurrence of neoplasms in the oral cavity is to relate the occurrence of certain lesions to a specific population, as well as to identify possible factors that may influence the development of these lesions and malignant transformation of dysplastic lesions. Such research is of considerable importance in providing data that facilitate the elaboration of preventive actions and treatment plans, as well as the possibility of comparison between population groups 2 .
Several epidemiological studies that consider case series of neoplasms and dysplastic lesions have been conducted in Brazil. Studies of this nature enable the identification of the user profiles of the service in question and, indirectly, recommendation of the possible strategic actions to be implemented for dealing with the oral condition of a given population ${ }^{3-5}$.

The objective of this study was to record and analyze the histopathological reports of benign and malignant neoplasms as well as dysplastic lesions diagnosed over a 19-year period in the Oral and Maxillofacial Pathology Service of the Dentistry Department of a higher education institution.

\section{Materials and methods}

This study was submitted to the Research Ethics Committee of the BAHIANA - School of Medicine and Public Health and approved under opinion number 3.460.736 (CAAE 10055619.0.0000.5544). A retrospective study was conducted based on the analysis of histopathological reports of biopsies sent to the Pathological Anatomy Service of the BAHIANA - School of Medicine and Public Health from 2001 to 2019.

All reports that described diagnoses of neoplasms and dysplastic lesions were selected. The frequencies of the variables of patient sex and age, as well as diagnostic suspicion, histopathological diagnosis, and location of the lesions, were analyzed. After reading the reports, the respective diagnoses were classified into different groups according to the nature of the neoplasms and dysplasia. (Figure 1). Cases with insufficient clinical information or samples available for anatomopathological examination to reach a final diagnosis were only quantified but not described in the text. They were grouped as "others". 


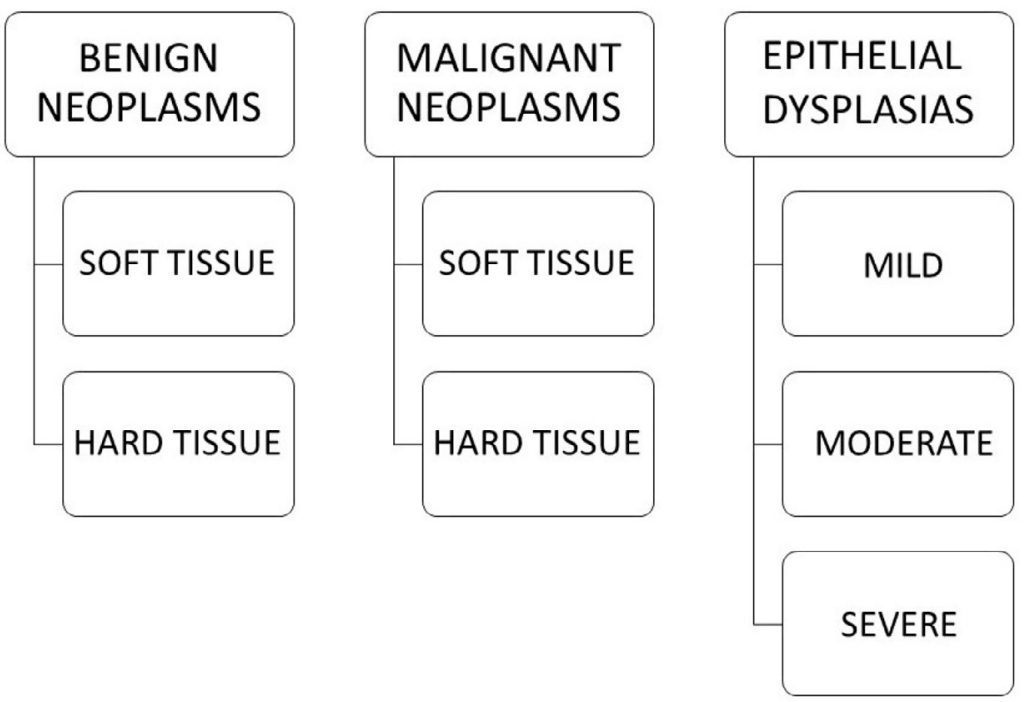

The division of neoplasms and epithelial dysplasias by age group was based on the distribution defined by the Brazilian Institute of Geography and Statistics ${ }^{6}$, which comprises four large groups, namely children (0-14 years), young people (15-24 years), adults (25-64 years), and the elderly (65 years and above).

For data collection and analysis, Microsoft Excel 365 software was used to develop a spreadsheet that was built specifically for the study. Regarding qualitative variables, the data were obtained from a one-dimensional frequency table, describing their respective percentages.

\section{Results}

In general, 3,068 histopathology reports were collected for the period covered by the study and $16,9 \%(\mathrm{n}=520)$ and $3,8 \%(n=118)$ corresponded to neoplasms and dysplastic lesions, respectively. Of the total neoplasms, $78.2 \%(n=$ 407) corresponded to benign neoplasms and $21.7 \%(n=113)$ to malignant tumors. Over the 19-year period of the study, it was demonstrated that the highest absolute number of benign neoplasms corresponded to $2009(9.8 \%$, $n=40), 2012(9.8 \%, n=40)$, and $2018(8.5 \%, n=35)$. Regarding malignant neoplasms, their frequency was always lower over the years, with constant fluctuation (Graphic 1).

\section{Graphic 1. Annual distribution of benign and malignant neoplasms}

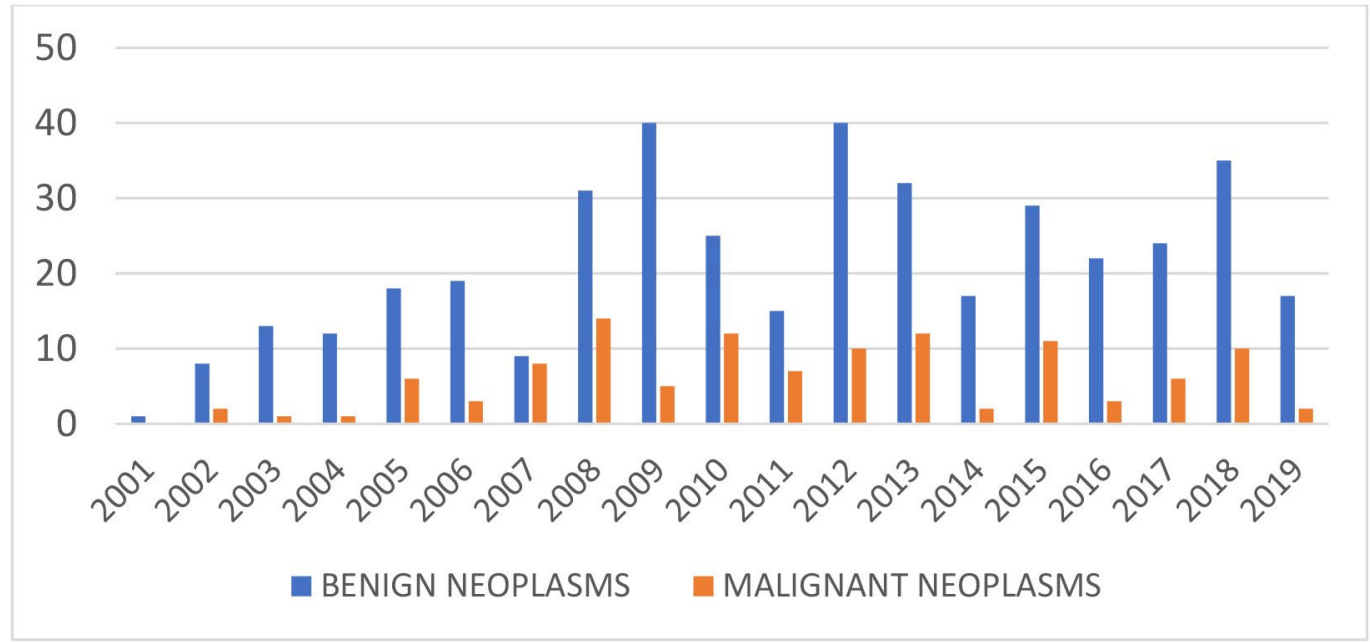


Table 1 illustrates the distribution of the most frequent benign neoplasms, which were more frequent in women $(60.1 \%, n=245)$ and in individuals between 25 and 64 years of age $(59.4 \%, n=242)$. Of the total benign neoplasms, 49.3\% $(n=201)$ corresponded to soft tissue tumors and $50.1 \%(n=204)$ were intraosseous. Two histopathology reports $(0.4 \%)$ did not clarify the histogenesis of the benign neoplasms. Of the total intraosseous benign neoplasms mentioned, $88.2 \%(n=180)$ were odontogenic in origin. Among the most prevalent benign tumors, there was a higher frequency of odontogenic tumors like ameloblastoma $(20.3 \%, n=83)$, which was followed by papilloma (10.8\%. $n=44)$, compound odontoma $(10 \%, n=41)$, pleomorphic adenoma (9.3\%. $n=38)$, lipoma $(8.3 \%, n=34)$, and hemangioma $(7.6 \%, n=31)$. The anatomical site most affected by the development of benign tumors was the jaw $(39.3 \%, n=160)$, followed by the maxilla $(13.5 \%, n=55)$, palate $(12 \%, n=49)$, and jugal mucosa $(9.3 \%, n=38)$.

Table 1. Most frequent diagnoses of benign neoplasms according to age, sex and lesion location. Pathological Anatomy Laboratory of EBMSP, 2000 to 2019

\begin{tabular}{|c|c|c|}
\hline VARIABLES & & BENIGN NEOPLASMS $(n=407)$ \\
\hline \multirow[t]{5}{*}{ AGE } & $\begin{array}{l}0-14 \\
(n=50)\end{array}$ & Compound odontoma $(n=19 ; 4.6 \%)$ \\
\hline & $\begin{array}{l}15-24 \\
(n=59)\end{array}$ & Ameloblastoma $(n=15 ; 3.6 \%)$ \\
\hline & $\begin{array}{l}25-64 \\
(n=242)\end{array}$ & Ameloblastoma $(n=45 ; 11 \%)$ \\
\hline & $\begin{array}{l}65 \text { and above } \\
(n=37)\end{array}$ & $\begin{array}{l}\text { Papilloma }(n=7 ; 1.7 \%) \\
\text { Lipoma }(n=7 ; 1.7 \%) \\
\text { Ameloblastoma }(n=7 ; 1.7 \%)\end{array}$ \\
\hline & $\begin{array}{l}\text { No information } \\
(n=19)\end{array}$ & Ameloblastoma $(n=7 ; 1.7 \%)$ \\
\hline \multirow[t]{2}{*}{ SEX } & $\begin{array}{l}\text { Female } \\
(n=245)\end{array}$ & Ameloblastoma $(n=50 ; 12.3 \%)$ \\
\hline & $\begin{array}{l}\text { Male } \\
(n=162)\end{array}$ & Ameloblastoma $(n=33 ; 8.1 \%)$ \\
\hline \multirow[t]{9}{*}{ LOCATION* } & $\begin{array}{l}\text { Jaw } \\
(n=160)\end{array}$ & Ameloblastoma $(n=67 ; 16.5 \%)$ \\
\hline & $\begin{array}{l}\text { Maxilla } \\
(n=55)\end{array}$ & Compound odontoma $(n=18 ; 4.4 \%)$ \\
\hline & $\begin{array}{l}\text { Palate } \\
(n=49)\end{array}$ & Pleomorphic adenoma $(n=23 ; 5.6 \%)$ \\
\hline & $\begin{array}{l}\text { Jugal mucosa } \\
(\mathrm{n}=38)\end{array}$ & Hemangioma $(n=5 ; 1.2 \%)$ \\
\hline & $\begin{array}{l}\operatorname{Lip} \\
(n=29)\end{array}$ & Hemangioma ( $n=10 ; 2.4 \%)$ \\
\hline & $\begin{array}{l}\text { Tongue } \\
(\mathrm{n}=26)\end{array}$ & Papilloma (n= 9; 2.2\%) \\
\hline & $\begin{array}{l}\text { Floor of the mouth } \\
(n=7)\end{array}$ & Lipoma $(n=3 ; 0,7 \%)$ \\
\hline & $\begin{array}{l}\text { No specified } \\
(n=64)\end{array}$ & Lipoma (n= 18; 28.1\%) \\
\hline & $\begin{array}{l}\text { No information } \\
(n=8)\end{array}$ & Ameloblastoma $(n=3 ; 0.7 \%)$ \\
\hline
\end{tabular}

*The total of reported locations is non coincident with the total of benign neoplasms because some lesions were reported in more than one site. 
As regards malignant neoplasms, Table 2 describes their frequencies. It was found that the highest number of cases were concentrated in males $(61.9 \%, n=70)$ with the predominant age group between 25 and 64 years $(63.7 \%, n=72)$. Of the total malignant neoplasms, $84.9 \%(n=96)$ corresponded to soft tissue tumors, $11.5 \%$ ( $n$ $=13)$ were malignant neoplasms with histogenesis to be clarified and 3.5\% $(n=4)$ were intraosseous. Malignant tumors described in the reports included squamous cell carcinoma $(67.2 \%, n=76)$, followed by mucoepidermoid carcinoma $(7.9 \%, n=9)$. The most frequent location of this group of lesions was the jaw $(27.4 \%, n=31)$, followed by the tongue $(20.3 \%, n=23)$, palate $(19.4 \%, n=22)$, and floor of the mouth $(13.2 \%, n=15)$.

Table 2. Most frequent diagnoses of malignant neoplasms according to age, sex and lesion location. Pathological Anatomy Laboratory of EBMSP, 2000 to 2019

\begin{tabular}{|c|c|c|}
\hline VARIABLES & & MALIGNANT NEOPLASMS $(n=113)$ \\
\hline \multirow[t]{6}{*}{ AGE } & $0-14$ & Squamous cell carcinoma $(n=1 ; 0.8 \%)$ \\
\hline & $(n=3)$ & Osteosarcoma $(n=1 ; 0.8 \%)$ \\
\hline & $\begin{array}{l}15-24 \\
(n=6)\end{array}$ & $\begin{array}{l}\text { Malignant neoplasm with histogenesis to be clarified } \\
(n=5 ; 4.3 \%)\end{array}$ \\
\hline & $\begin{array}{l}25-64 \\
(n=72)\end{array}$ & Squamous cell carcinoma $(n=53 ; 46.9 \%)$ \\
\hline & $\begin{array}{l}65 \text { and above } \\
(n=26)\end{array}$ & Squamous cell carcinoma $(n=18 ; 15.9 \%)$ \\
\hline & $\begin{array}{l}\text { No information } \\
(n=6)\end{array}$ & Squamous cell carcinoma $(n=4 ; 3.5 \%)$ \\
\hline \multirow[t]{2}{*}{ SEX } & $\begin{array}{l}\text { Female } \\
(n=43)\end{array}$ & Squamous cell carcinoma ( $n=25 ; 22.1 \%)$ \\
\hline & $\begin{array}{l}\text { Male } \\
(n=70)\end{array}$ & Squamous cell carcinoma ( $n=51 ; 61.9 \%)$ \\
\hline \multirow[t]{9}{*}{ LOCATION* } & $\begin{array}{l}\text { Jaw } \\
(n=31)\end{array}$ & Squamous cell carcinoma ( $n=16 ; 14.1 \%)$ \\
\hline & $\begin{array}{l}\text { Maxilla } \\
(n=8)\end{array}$ & Squamous cell carcinoma $(n=3 ; 2.6 \%)$ \\
\hline & $\begin{array}{l}\text { Palate } \\
(n=22)\end{array}$ & Squamous cell carcinoma $(n=13 ; 11.5 \%)$ \\
\hline & $\begin{array}{l}\text { Jugal mucosa } \\
(n=6)\end{array}$ & Squamous cell carcinoma $(n=6 ; 5.3 \%)$ \\
\hline & $\begin{array}{l}\operatorname{Lip} \\
(n=8)\end{array}$ & Squamous cell carcinoma $(n=7 ; 6.1 \%)$ \\
\hline & $\begin{array}{l}\text { Tongue } \\
(n=23)\end{array}$ & Squamous cell carcinoma $(n=20 ; 17.6 \%)$ \\
\hline & $\begin{array}{l}\text { Floor of the mouth } \\
(n=15)\end{array}$ & Squamous cell carcinoma $(n=13 ; 11.5 \%)$ \\
\hline & $\begin{array}{l}\text { No specified } \\
(n=28)\end{array}$ & Squamous cell carcinoma $(n=18 ; 64.2 \%)$ \\
\hline & $\begin{array}{l}\text { No information } \\
(n=1)\end{array}$ & $\begin{array}{l}\text { Malignant neoplasm with histogenesis to be clarified } \\
(n=1 ; 0.8 \%)\end{array}$ \\
\hline
\end{tabular}

*The total of reported locations is non coincident with the total of malignant neoplasms because some lesions were reported in more than one site. 
Of a total of 520 histopathology reports referring to neoplasms, there was a variation of 2-6 diagnostic hypotheses per neoplasm and $62 \%(n=321)$ corresponded with the diagnostic hypotheses raised during the clinical examination, whereas 34\% ( $n=179)$ did not show agreement. Four percent $(n=20)$ of the reports did not present a definite diagnostic hypothesis (Graphic 2) and in 3.8\% of cases an immunohistochemical study was recommended.

Graphic 2. Comparison between clinical and histopathological diagnoses as well as reports with no diagnostic hypothesis

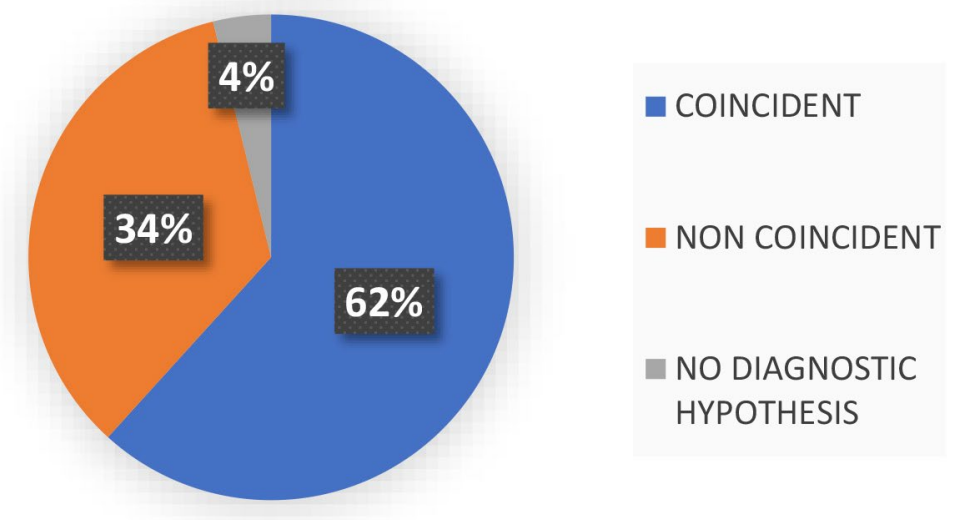

Graphic 3 illustrates the origin of biopsies of the oral neoplasms. Of the total biopsies, $71.1 \%$ came from the Outpatient Care Teaching Clinic of the institution $(n=370), 9.4 \%$ were sent by public service professionals $(n=49)$, 6.3\% were from the Residency Program in Oral and Maxillofacial Surgery and Traumatology of the Secretary of Health of the State of Bahia (SESAB) $(n=33)$ and $5.1 \%$ from the private sector $(n=27)$. Trade associations $(n=19)$ and other higher education institutions $(n=9)$ also sent biological material for analysis, although their percentage was lower $(3.6 \%$ and $1.7 \%$, respectively). Less than $3 \%$ of the reports $(2.5 \% ; n=13)$ did not describe the origin of the surgical specimens.

Graphic 3. Origin of the biopsies of benign and malignant neoplasms

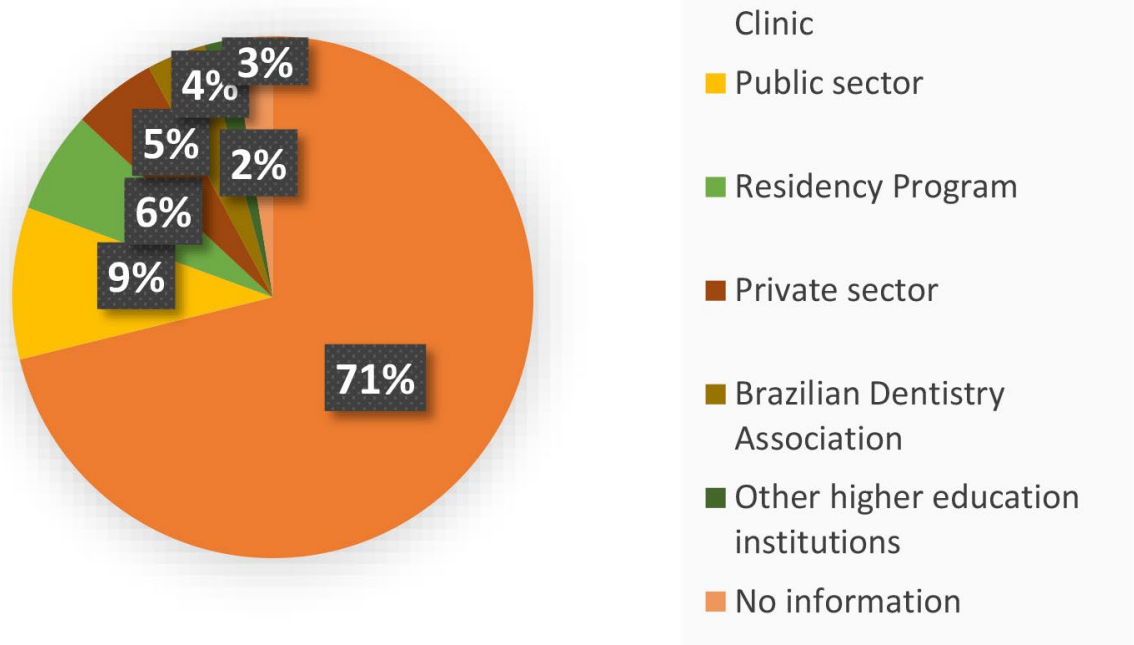

Histopathological diagnoses of epithelial dysplasia accounted for $3.8 \%(n=118)$ of the total sample. The most frequent grade of dysplasia was mild, which corresponded to $68.6 \%(n=81)$ of the set of dysplastic lesions, followed by moderate and severe epithelial dysplasia (20.4\%, $n=24$ and $11 \%, n=13$, respectively). Table 3 illustrates the distribution of dysplasia grades and indicates a higher occurrence in men $(50.8 \%, n=60)$ and in individuals between 25 and 64 years of age $(61 \%, n=72)$. The anatomical site most affected by dysplasias was the palate $(22.8 \%, \mathrm{n}=27)$, followed by the jaw $(21.1 \%, \mathrm{n}=25)$ and tongue $(20.3 \%, \mathrm{n}=24)$. 
Table 3. Distribution of epithelial dysplasia according to age, sex and lesion location. Pathological Anatomy Laboratory of EBMSP, 2000 to 2019

\begin{tabular}{|c|c|c|c|c|}
\hline VARIABLES & & $\begin{array}{l}\text { MILD EPITHELIAL } \\
\text { DYSPLASIA } \\
(n=81)\end{array}$ & $\begin{array}{c}\text { MODERATE } \\
\text { EPITHELIAL } \\
\text { DYSPLASIA } \\
(n=24) \\
\end{array}$ & $\begin{array}{l}\text { SEVERE EPITHELIAL } \\
\text { DYSPLASIA } \\
(n=13)\end{array}$ \\
\hline \multirow[t]{5}{*}{ AGE } & $0-14$ & - & - & - \\
\hline & $15-24$ & $n=3(3,7 \%)$ & - & - \\
\hline & $25-64$ & $n=48(59,2 \%)$ & $n=16(66,6 \%)$ & $\mathrm{n}=8(61,5 \%)$ \\
\hline & 65 and above & $n=26(32 \%)$ & $n=6(25 \%)$ & $n=4(30,7 \%)$ \\
\hline & No information & $n=4(4,9 \%)$ & $\mathrm{n}=2(8,3 \%)$ & $\mathrm{n}=1(7,6 \%)$ \\
\hline \multirow[t]{2}{*}{ SEX } & Female & $n=42 ; 51,8 \%$ & $n=11(45,8 \%)$ & $n=5(38,4 \%)$ \\
\hline & Male & $n=39 ; 48,1 \%$ & $n=13(56,5 \%)$ & $n=8(61,5 \%)$ \\
\hline \multirow[t]{8}{*}{ LOCATION } & Jaw & $n=20(24,6 \%)$ & $n=3(12,5 \%)$ & $\mathrm{n}=2(15,3 \%)$ \\
\hline & Maxilla & $n=6(74 \%)$ & $n=4(16,6 \%)$ & - \\
\hline & Palate & $n=18(22,2 \%)$ & $\mathrm{n}=7(29,1 \%)$ & $n=2(15,3 \%)$ \\
\hline & Jugal mucosa & $n=17(20,9 \%)$ & $n=4(16,6 \%)$ & $\mathrm{n}=2(15,3 \%)$ \\
\hline & Lip & $n=8(9,8 \%)$ & $n=4(16,6 \%)$ & $\mathrm{n}=1(7,6 \%)$ \\
\hline & Tongue & $n=13(16 \%)$ & $n=6(25 \%)$ & $\mathrm{n}=5(38,4 \%)$ \\
\hline & No specified & $n=9(11,1 \%)$ & $\mathrm{n}=1(4,1 \%)$ & - \\
\hline & No information & $n=1(1,2 \%)$ & $n=1(4,1 \%)$ & - \\
\hline
\end{tabular}

\section{Discussion}

The present study analyzed 3,068 histopathology reports, among which $16.9 \%$ represented oral neoplasms. In the study by Trevisan et al. $\frac{5}{\text { that }}$ was conducted over a 12-year period, $21.4 \%$ of the 707 histopathology reports of lesions submitted for biopsy were of oral neoplasms and $19 \%$ of the 762 cases analyzed in the 16-year retrospective

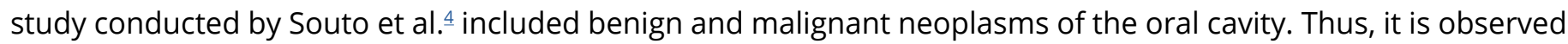
that neoplasms represent a significant portion of the total lesions that affect the oral and maxillofacial complex and, therefore, an epidemiological study evaluating the occurrence of such lesions is of great importance so that the dentist can make a decision about the best therapeutic option, as well as about possible preventive measures².

In the present study, we chose to use the classification of age groups according to the criteria of the Brazilian Institute of Geography and Statistics ${ }^{6}$. Regarding the distribution of neoplasms by age group, individuals between 25 and 64 years of age were the most affected by benign and malignant neoplasms. In the age group of 0-14 years there was a higher frequency of benign neoplasms. A 21-year retrospective epidemiological survey conducted by Rocha et al.? which selected only cases diagnosed as benign neoplasms, observed its greater involvement in the fourth decade of life but with a balanced distribution among age groups. In other studies, malignant lesions were more frequent in the age group of 40-80 years and over ${ }^{8}$, with the most affected individuals having mean age of 58.9 years ${ }^{4}$. In their epidemiological survey, Trevisan et al. ${ }^{5}$ concluded that benign neoplasms were more frequent in individuals aged 51-60 years, whereas malignant neoplasms were predominant in patients older than 60 years of age. This greater involvement of malignant lesions in older patients can be attributed to exposure over time to environmental factors with known carcinogenic potential, such as tobacco and alcohol? 
In the age group comprising individuals aged 0-14 years, the most prevalent lesion among benign neoplasms was compound odontoma (35.8\%) and, among malignant ones, squamous cell carcinoma $(1.8 \%)$ and osteosarcoma (1.8\%) were highlighted. In the survey by Lima et al. 9 , which analyzed 625 biopsies of maxillomandibular complex lesions in children in a retrospective 20-year study, the same number of cases of benign neoplasm $(n=50)$ were found as in the present study, with fibroma standing out in this context. Among the odontogenic tumors $(6.7 \%)$, which were analyzed separately, the most frequent lesion was odontoma (4.32\%). A small percentage of malignant neoplasms (1.2\%) was reported, with rhabdomyosarcoma, neuroblastoma, and Langerhans cell histiocytosis being the most prevalent diagnoses $(0.32 \%)$. Also, in this same study, odontoma was considered the most prevalent odontogenic tumor, which confirms the data found in the present study.

Sousa et al..$^{10}$, analyzing 2,356 biopsies performed in patients up to 14 years of age over a period of 15 years, observed that 180 lesions were benign (7.6\%) and 31 were malignant neoplasms (1.3\%), with the most frequent lesions being papilloma and Langerhans cell histiocytosis, respectively. This study, which also analyzed odontogenic tumors separately (6.8\%), had compound and complex odontomas as the most frequent entities of this group (4.8\%). Also, in the study by Franklin and Jones ${ }^{11}$, in which 4,406 biopsies of patients between 0 and 16 years of age in a 30-year period were analyzed, 114 benign oral neoplasms and 43 odontogenic tumors were observed, with the most frequent diagnoses being papilloma and compound odontoma, respectively. Among the malignant neoplasms, which corresponded to 31 cases, there were 6 main entities, including Langerhans cell histiocytosis, mucoepidermoid carcinoma, multiple endocrine neoplasm, neurosarcoma, rhabdomyosarcoma, and squamous cell carcinoma. When the results of the studies cited were compared with those of the present study, it was observed that all of them analyzed histopathology reports for a period of more than 15 years and, in all of them, the number of benign neoplasms was significantly higher than that of malignant neoplasms in children. Likewise, as observed in our study results, odontoma was the benign neoplasm most described in the studies cited and there was great variation in the most common types of malignant neoplasms represented in this age group.
Regarding the distribution by sex, it was found that benign neoplasms affected more female patients, whereas malignant neoplasms were more frequent in male patients. This is corroborated by other studies and some of them justify this fact with the lower demand of men for health services $4,7,, 12$." However, it is worth noting that exposure to known carcinogenic environmental factors has been equalized between the sexes, possibly due to the change in the social behavior of women, who have long working hours and often develop harmful habits, such as smoking and drinking ${ }^{13}$. However, even in light of this current scenario, the National Cancer Institute Jose Alencar Gomes da Silva, an organ of the Ministry of Health, when estimating the number of new cases of oral cancer expected for Brazil for each year of the 20202022 triennium, concluded that there is an estimated risk of 10.69 new cases for every 100,000 men and 3.71 for every 100,000 women ${ }^{14}$, which indicates that there is still a higher incidence of cancer in male patients.

In the present study, the most frequent benign neoplasms were ameloblastoma, papilloma, and compound odontoma. In a 10-year retrospective study, Mendez et al. ${ }^{12}$ defined fibroma as the most common benign neoplasm and, among odontogenic tumors, the most prevalent were keratocystic odontogenic tumors and odontoma. More recently, in 2017 , the keratocyst was reclassified by WHO as an odontogenic cyst ${ }^{15}$ and this new classification criterion was adopted in this study. The study by Rocha et al. , from which odontogenic tumors and salivary gland lesions were excluded, reported that the most frequent entities among benign neoplasms were fibroma, papilloma, and hemangioma, all of which are soft tissue lesions. In the same study, the number of benign intraosseous neoplasms was lower than that observed for soft tissue tumors. The epidemiological study by Silva et al. ${ }^{16}$ shows that the group of benign neoplasms, which had the highest representation among all groups of lesions (33\%), presented fibroma as the prominent histopathological diagnosis. There were no reports of cases of benign neoplasms in hard tissue.

In our study, a total of 113 malignant neoplasms were found, which corresponds to $3.6 \%$ of all histopathology reports collected. Squamous cell carcinoma was the most frequent neoplasm in this group. Some studies 3,4,12,17,18 also found a smaller number of malignant neoplasms compared with benign neoplasms and squamous cell carcinoma as 
the most prevalent lesion, whereas others $5,8,19$ cited epidermoid carcinoma as the most common diagnosis. Regarding the location of neoplasms present in soft or intraosseous tissues, the intraosseous neoplasms accounted for only 3.5\% of the total malignant neoplasms. In the literature, there was no description of absolute numbers or percentages of the occurrence of intraosseous malignant neoplasms in different pathology services as most authors aimed to document the case studies of neoplasms without declaring this type of information.

In relation to the anatomical location of the lesions, the site most affected by benign and malignant neoplasms was the mandible. Other studies with the same type of classification observed different results and described the most common anatomical sites affected by benign neoplasms as the jugal mucosa ${ }^{7}$ and the upper lip ${ }^{8}$, whereas for malignant neoplasms, the most prevalent anatomical site in the research were the tongue ${ }^{8}$. Such discrepancy may be related to populations' variability described in several studies.

Of the total cases of neoplasms, $62 \%$ presented correspondence between the clinical diagnosis and the histopathological diagnosis and there was a variation of 2-6 diagnostic hypotheses per neoplasm. In the study by Silva et al. ${ }^{20}$, which compared clinical, surgical, and histopathological diagnoses, agreement in $56.67 \%$ of cases and reports of 1-2 diagnostic hypotheses for each neoplasm were observed. In the work of Vier et al. $\stackrel{18}{ }$, who analyzed 692 biopsies, 79.9\% had coincident clinical and histopathological diagnoses, but the high confirmation rate was attributed to the fact that biopsies were performed in a specialized oral diagnostic service. It is worth noting that, although the present study was also carried out in a similar service, this correlation between diagnoses was analyzed only for oral neoplasms, whereas other studies considered all types of lesions.

It is important to point out that for the correct histopathological diagnosis to be achieved, the specimen of the lesion must be sufficiently large for analysis, accompanied by a clinical report, and have a detailed description of the lesion, in addition to at least one diagnostic hypothesis ${ }^{21}$. In $4 \%$ of the biopsy files sent to the Pathology Service of EBMSP, there was no information about the surgical specimen, nor was there information on any suspected diagnosis. In some cases in this study, the biopsy material did not allow the conclusive histopathological diagnosis of the lesion. Given the above, an immunohistochemical study was recommended in $3.8 \%$ of cases, a method based on the recognition of certain tumor markers, contributing to a more accurate diagnosis with better prognosis ${ }^{22}$.

Because it is considered a potentially malignant lesion, histopathology reports of epithelial dysplasia were also included in this study. In the present survey, the most common lesion in this group was mild epithelial dysplasia. This finding corroborates the results of other studies ${ }^{17}$, although in others, the most prevalent grade of dysplasia was moderate ${ }^{4}$. In general, epithelial dysplasias affected more male individuals aged between 25 and 64 years, with the palate as the primary anatomical site. Because malignant lesions are more frequent in males, it is consistent that such lesions with neoplastic potential are more frequent in patients of the same sex. In contrast, in the study by Souto et al. 4 , there was a balance in the number of cases between the sexes, with greater involvement at an average age of 51 years and in the lower lip.

\section{Conclusions}

The benign neoplasms were more frequent in patients of the female sex and individuals between 25 and 64 years of age. The most prevalent benign tumors were ameloblastoma, papilloma and compound odontoma. The malignant neoplasms were more frequent in the male sex and patients between 25 and 64 years of age. Among the malignant tumors, the squamous cell carcinoma was the most common lesion. The epithelial dysplasias had higher occurrence in patients of the male sex and individuals between 25 and 64 years of age. The most frequent grade of dysplasia was the mild.

The epidemiological research is of considerable importance in providing data of a specific population and it can help the health professionals with the elaboration of preventive actions and treatment plans. It is important reinforce the necessity of the appropriate filling out of clinical files for the correct establishment of histopathological diagnosis. 


\section{Author contributions}

Assis MSA carried out the data survey, participated in the analysis of the results and writing of the manuscript. Reis SRA participated in the analysis and description of the results and Medrado ARAP critically revised the text.

\section{Competing interests}

No financial, legal or political competing interests with third parties (government, commercial, private foundation, etc.) were disclosed for any aspect of the submitted work (including but not limited to grants, data monitoring board, study design, manuscript preparation, statistical analysis, etc.).

\section{References}

1. Kumar V, Abbas A.K, Aster J.C. Neoplasia. In Robbins Basic Pathology. Rio de Janeiro: Elsevier; 2013. p. 161-69.

2. Dias Neto B, Medrado AP, Reis SRA. Evaluation of pathology extension activity of EBMSP - a ten years follow-up (20012009). J Dent Public Health. 2012;3(1):3-15. http://dx.doi. org/10.17267/2238-2720revbahianaodonto.v3i1.27

3. Santos MMMC, Santos PSS, Souza RS, Marques MAC, Dib LL. A retrospective study of oral lesions in the clinic of Stomatology of Universidade Paulista (UNIP). J Health Sci Inst. 2013;31(3):248-53.

4. Souto MLS, Piva MR, Martins-Filho PRS, Takeshita WM. Maxillofacial lesions: a survey of 762 cases from the Federal University of Sergipe, Brazil. Rev Odontol UNESP. 2014;43(3):185190. http://dx.doi.org/10.1590/rou.2014.029

5. Trevisan B, Wagner JCB, Volkweis MR. Histopathological diagnosis of oral lesions. The experience of maxillofacial surgery service of the hospital complex Santa Casa de Porto Alegre. RFO. 2013;18(1):55-60. http://dx.doi.org/10.5335/rfo.v18i1.3017

6. Instituto Brasileiro de Geografia e Estatística. 2010 Population Census [Internet]. 2010. Available in: https://www.ibge.gov.br/ en/statistics/social/population/18391-2010-population-census. html?edicao=21738\&t=sobre

7. Rocha DAP, Oliveira LMM, Sousa LB. Oral Benign Neoplasias: Epidemiological Study - 21 years (1982-2002). Rev Odontol Univ São Paulo. 2006;18(1):53-60.

8. Moreira ARO, Oliveira CDM, Silva RR, Lopes FF, Bastos EG. Epidemiological survey of oral and maxillofacial epithelial diseases: a 20-year history. Rev Gaúcha Odontol. 2011;59(1):65-70.

9. Lima GS, Fontes ST, Araújo LMA, Etges A, Tarquinio SBC, Gomes APN. A survey of oral and maxillofacial biopsies in children: a single-center retrospective study of 20 years in Pelotas-Brazil. J Appl Oral Sci. 2008;16(6):397-402. http://dx.doi.org/10.1590/ S1678-77572008000600008
10. Sousa FB, Etges A, Corrêa L, Mesquita RA, Araújo NS. Pediatric oral lesions: a 15-year review from Sao Paulo, Brazil. J Clin Pediatr Dent. 2002;26(4):413-8. http://dx.doi.org/10.17796/ jcpd.26.4.47n1670jr961×566

11. Jones AV, Franklin CD. An analysis of oral and maxillofacial pathology found in children over a 30-year period. Int J Paediatr Dent. 2006;16(1):19-30. http://dx.doi.org/10.1111/j.1365263X.2006.00683.X

12. Mendez M, Carrard VC, Haas AN, Lauxen IS, Barbachan JJD, Rados PV et al. A 10-year study of specimens submitted to oral pathology laboratory analysis: lesion occurrence and demographic features. Braz Oral Res. 2012;26(3):235-41. http:// dx.doi.org/10.1590/S1806-83242012000300009

13. Neville BW, Day TA. Oral cancer and precancerous lesions. CA Cancer J Clin. 2002; 52(4):195-215. http://dx.doi.org/10.3322/ canjclin.52.4.195

14. Instituto Nacional de Câncer José Alencar Gomes da Silva. Estimate/2020 - Cancer Incidence in Brazil. [Internet]. 2019. Available in: https://rbc.inca.gov.br/revista/index.php/revista/ article/download/927/560

15. Tolentino ES. Updated WHO classification for odontogenic tumors: what has changed? RFO. 2018;23(1):119-123. http:// dx.doi.org/10.5335/rfo.v23i1.7905

16. Silva TCG, Gonnelli FAS, Rocha LA, Palma LF. Epidemiological survey of biopsies performed in a dental school clinic in the period from 2011 to 2018. Rev Odontol Araçatuba. 2019; 40(1):52-55.

17. Martins JC, Essvein G, Vargas-Ferreira F, Silva AD, Neves M. Prevalence of oral lesions diagnosed at the ULBRA Canoas of Dental Diagnosis Service. Stomatos. 2017; 23(44):24-32.

18. Vier FV, Rockenbach MIB, Gabriel JG, Yurgel LS, Cherubini $\mathrm{K}$, Figueiredo MAZ. Histopathological diagnoses of a pathology laboratory at PUCRS stomatology service, in the years of 2000 to 2002 , and its relation with the clinical diagnosis. Rev Odonto Ciênc. 2004; 19(46):382-88.

19. Xavier JC, Andrade SC, Arcoverde CAL, Lucena KCR, Cavalcanti UDNT, Carvalho AAT. Lifting epidemiologic of the bucal injuries presented by patients attended at Stomatology service of the Universidade Federal de Pernambuco during the period of January of 2006 to July of 2008. Int J Dent. 2009;8(3):135-139.

20. Silva TFA, Souza RB, Rocha RD, Araújo FAC, Morais HHA. Survey of Biopsies Performed at the Department of Oral and Maxillofacial Surgery, State University of Rio Grande do Norte, Brazil. Rev Cir Traumatol Buco-Maxilo-Fac. 2011;11(2):91-100.

21. Barbosa RPS, Paiva MDEB, Rodrigues TLC, Rodrigues FG. Valuing the biopsy in the dentistry practice. Arq Odontol. 2005;41(4):318-328.

22. Bacarelli JC. Immunohistochemistry: applications in oral pathology. Rev Ciênc Méd. 1995;4(2):66-70. 